\title{
Online relationship marketing: Evolution and theoretical insights into online relationship marketing
}

\begin{abstract}
Purpose - Review the past, current, and future trends in empirical research and theoretical insights into online relationship marketing.

Methodology - Review over 100 empirical and theoretical studies in the online relationship marketing from top marketing and management journals.

Findings - This study examined three areas pertinent to online relationship marketing: a) The evolution of online relationship marketing from pre-1990s to the present, which offers a temporal snapshot of changes in and an overview of the critical components that make up the structure of online relationship marketing; b) Key theoretical perspectives are underlying the development of online relationship marketing; and c) Empirical insights into online relationship marketing. In general, online relationship marketing has evolved from customers being passive receivers of online information and services to active co-producers and value cocreators.
\end{abstract}

Research implications - The paper identifies future research areas, including multiple layers of interactions, use of new technologies and platforms, and the dark side of online communications.

Originality - We dedicated summary tables for each area, highlighting key findings, which in turn suggest a series of managerial recommendations for facilitating efficient, effective buyerseller interactions and maximising firm performance in relation to online relationship marketing.

Keywords - online relationship marketing, relationship marketing, e-commerce, new technology, evolution, theory, theoretical insights, empirical research. 


\section{Overview}

Relationship marketing has been shown to generate strong customer relationships that enhance customer satisfaction, customer loyalty, and firm profits (Firdaus and Kanyan, 2014). It stresses the importance of continuous interactions between the seller and buyer in order to develop a long-term relationship (Jain, Kamboj, Kumar and Rahman, 2018; Palmatier, Dant, Grewal, and Evans, 2006). Additionally, the increasing interest in online shopping has prompted many companies to move into cyberspace (Jensen and Wagner, 2018; Thaichon, 2017). The Internet allows service providers to grow and deliver a unique opportunity to expand their business. Nevertheless, the impact of the Internet and technology on relationship marketing are often not adequately investigated, leading to overstated hypothetical predictions of its future potential (Hart, Doherty, and Ellis-Chadwick, 2000). In many circumstances, the resources devoted to developing and retaining e-platforms are fruitless. Therefore, it is imperative to advance our knowledge of online relationship marketing.

To map the evolution of online relationship marketing and provide a thorough review of research insights, we highlight some relevant trends in the composition of online relationship marketing in response to technological change, which leads to some predictions regarding the future of online relationship marketing. In this article, we examine three areas pertinent to online relationship marketing: a) The evolution of online retailing from pre-1990s to the present, which offers a temporal snapshot of changes in and an overview of the key components that make up the structure of online relationship marketing; b) Key theoretical perspectives underlying the development of online retailing; c) Empirical insights into online relationship marketing; and d) Future research directions suggesting key research areas in online relationship marketing.

\section{Evolution of online relationship marketing}


This study presents a novel idea on the evolution of online relationship marketing by

identifying four main phases: Phase One (the pre-1990 period), Phase Two (the 1990s), Phase

Three (2000s), and Phase Four (2010s) (Table 1). Each of these phases is characterised by

different key trends and disruptions. In general, online relationship marketing has evolved from

customers being passive receivers of online information and services to active co-producers

and value co-creators.

Table 1: Evolution of online relationship marketing

\begin{tabular}{|c|c|c|c|c|}
\hline & $\begin{array}{l}\text { Develop online promotional strategy } \\
\text { in line with customer gratification } \\
\text { and expectation to build a successful } \\
\text { relationship }\end{array}$ & $\begin{array}{c}\text { Design online systems and networks } \\
\text { to provide real time information and } \\
\text { create a relationship through } \\
\text { credibility }\end{array}$ & $\begin{array}{c}\text { Create a successful online } \\
\text { relationship based on customer } \\
\text { knowledge, social networks and e- } \\
\text { WOM }\end{array}$ & $\begin{array}{l}\text { Moving forward with value co- } \\
\text { creation and build cus tomer equity } \\
\text { through retention and repeat } \\
\text { purchase }\end{array}$ \\
\hline & Pre - 1990s & 1990 s to $2000 \mathrm{~s}$ & 2000 s to $2010 \mathrm{~s}$ & 2010 s to $2020 \mathrm{~s}$ \\
\hline Theories & Uses gratification theory & Signalling theory & $\begin{array}{l}\text { Social influence theory; Social capital } \\
\text { theory }\end{array}$ & $\begin{array}{l}\text { Value co-creation; Customer equity } \\
\text { theory }\end{array}$ \\
\hline $\begin{array}{l}\text { Relationship } \\
\text { with the buyer }\end{array}$ & $\begin{array}{l}\text { Customer relationships are } \\
\text { developed based on the quality, } \\
\text { accuracy and effectiveness of } \\
\text { communication. The advertising and } \\
\text { promotional strategy of a firm should } \\
\text { match the expectation of the } \\
\text { customers. }\end{array}$ & $\begin{array}{l}\text { A firm can build a relationship with } \\
\text { the customers by providing reliable } \\
\text { and specific signals on product } \\
\text { quality and pricing. The customers } \\
\text { expect value for money and will } \\
\text { evaluate options to minimise the risk } \\
\text { of information overload in the online } \\
\text { market. A firm can develop a long- } \\
\text { term relationship by designing } \\
\text { websites and user interface to } \\
\text { provide up to date information with } \\
\text { integrity and credibility. A successful } \\
\text { online relationship with customers } \\
\text { depends on the ability of a firm to } \\
\text { reduce the risk of purchasing and } \\
\text { consumption. }\end{array}$ & $\begin{array}{l}\text { Social influence provides a broader } \\
\text { foundation for a firm to develop a } \\
\text { relationship with customers. The } \\
\text { online platforms enable social } \\
\text { influence and a higher reach for a firm } \\
\text { in identifying global customers } \\
\text { beyond a physical target market. } \\
\text { Social capital is created in the } \\
\text { relationship between the firm and the } \\
\text { loyal customers. }\end{array}$ & $\begin{array}{l}\text { The relationship is created through a } \\
\text { customer centred decision-making } \\
\text { process where a customer is } \\
\text { considered as a co-producer. The } \\
\text { balance of power and a symmetric } \\
\text { relationship between the firm and the } \\
\text { customers are required to ensure } \\
\text { value co-creation. Customer equity is } \\
\text { created by building a loyal customer } \\
\text { base. The relationship depends on } \\
\text { continuous interaction where } \\
\text { financial return is justified through } \\
\text { repeat purchase over the lifecyle of a } \\
\text { customer. }\end{array}$ \\
\hline $\begin{array}{l}\text { Key trends and } \\
\text { disruptions }\end{array}$ & $\begin{array}{l}\text { Factual information, Consumer } \\
\text { psychology, positioning, user } \\
\text { gratification, imagination }\end{array}$ & $\begin{array}{l}\text { Complexity of information, data } \\
\text { manipulation, reliability, risk and } \\
\text { uncertainty, Integrity }\end{array}$ & $\begin{array}{l}\text { Social networks, loyalty, speed of } \\
\text { information, engagement, goal } \\
\text { congruence, sharing }\end{array}$ & $\begin{array}{l}\text { Co-creation, autonomy, innovation, } \\
\text { Life time value, Cus tomer retention, } \\
\text { intellectual capital }\end{array}$ \\
\hline Key insights & $\begin{array}{l}\text { It was challenging for firms to reach } \\
\text { customers online due to the lack of } \\
\text { personal and physical interaction } \\
\text { associated with a traditional store. } \\
\text { Also, during this stage, only a small } \\
\text { number of customers were able to } \\
\text { access the Internet. However, } \\
\text { pioneering firms needed to obtain a } \\
\text { broader understanding of customer } \\
\text { preference through computerised } \\
\text { simulation modelling and build a } \\
\text { strong relationship with customers. }\end{array}$ & $\begin{array}{l}\text { During this period, there was an } \\
\text { increase in the number of users } \\
\text { 'browsing' the Internet. A challenge } \\
\text { for online firms is to constantly } \\
\text { provide latest information and stay } \\
\text { ahead on competition. This era was } \\
\text { driven by a knowledge-rich } \\
\text { environment where firms were } \\
\text { required to design and manage real- } \\
\text { time market information systems to } \\
\text { build a relationship with customers. } \\
\text { The customers tend to trust firms } \\
\text { with a higher capacity to filter and } \\
\text { process online information on } \\
\text { product quality and pricing with } \\
\text { certainty and assurance. }\end{array}$ & $\begin{array}{l}\text { A firm should focus on identifying } \\
\text { and satisfying customers who has } \\
\text { the potential to influence the } \\
\text { behaviour of others through internet } \\
\text { and social networks. A monitoring } \\
\text { system is required to manage } \\
\text { customer correspondence online real- } \\
\text { time to ensure creation of positive e- } \\
\text { WOM. The present and future } \\
\text { consumption intentions and } \\
\text { objectives of customers should be } \\
\text { identified through proactive } \\
\text { information collection and analysis. } \\
\text { Firm should encourage customers to } \\
\text { share ideas and intentions based on } \\
\text { effective online communications. }\end{array}$ & $\begin{array}{l}\text { A firm should develop online } \\
\text { strategy to include sophisticated } \\
\text { networks, automated processes and } \\
\text { communications technology to } \\
\text { encougage customer participation in } \\
\text { value co-creation such as sharing of } \\
\text { innovative ideas. The customers } \\
\text { should be comfortable with the user } \\
\text { interface of the websites and social } \\
\text { media platforms to engage in } \\
\text { effective collaboration. Online firms } \\
\text { need to obtain post purchase } \\
\text { feedback, request product reviews, } \\
\text { and design loyalty schemes to } \\
\text { develop customer equity. }\end{array}$ \\
\hline $\begin{array}{l}\text { Illustrative } \\
\text { papers }\end{array}$ & $\begin{array}{l}\text { Bagozzi (1975), Bialaszewski and } \\
\text { Giallourakis (1985), Christian (1962), } \\
\text { Hawes (1987), John (1938), Markin } \\
\text { (1979), Moran (1963), Roshwalb } \\
\text { (1956), Steinberg and Plank (1987) }\end{array}$ & $\begin{array}{l}\text { Achrol and Kotler (1999), Alba et al. } \\
\text { (1997), Burke (1997), Hart et al. (2000), } \\
\text { Herbig and Milewicz (1995), } \\
\text { Parasuraman and Grewal (2000), } \\
\text { Tiwana (1998), Weiber and Kollmann } \\
\text { (1998), Yuan et al. (1998) }\end{array}$ & $\begin{array}{l}\text { Bart et al. (2005), Brown and Krishna } \\
\text { (2004), Bruner and Kumar, (2003). } \\
\text { Danaher et al. (2003), Dholakia et al. } \\
\text { (2009), Kozinets (2002), Kulviwat et } \\
\text { al. (2009), Thompson and Arsel } \\
\text { (2004), Stephen and Toubia (2010) }\end{array}$ & $\begin{array}{l}\text { Bartl et al. (2013), Dechant et al. } \\
\text { (2019), Dixit et al. (2019), Hollebeek et } \\
\text { al. (2019), Lim (2019), McColl- } \\
\text { Kennedy et al. (2019), Punyatoya } \\
\text { (2019), Shaltoni (2017), Steils et al. } \\
\text { (2019) }\end{array}$ \\
\hline
\end{tabular}


The first phase emerged through the novelty of using computer-related technology to obtain product information. The relationship was developed by a firm through the provision of information to induce customer motivation (Hawes, 1987; Steinberg and Plank, 1987). However, this also resulted in the emergence of the information overload, leading to the perceived ambiguity of online information (Bialaszewski and Giallourakis, 1985). In Phase 2, successful firms, developed over time online systems to deliver a clear signal to customers, increasing certainty and eliminating the crisis of ambiguity (Achrol and Kotler, 1999). The increase in online competition and the standardisation of the offers created a difficulty to sustain the online relationship with customers (Yuan et al., 1998). This led to Phase 3 in which firms were able to build a strong relationship through social interaction and engagement with their customers. The online systems, strategy, and customer interface were designed to accommodate social affiliation and knowledge sharing with customers (Kulviwat et al., 2009). Finally, Phase 4 originated through the advancement of social media platforms, leading to higher customer sovereignty. Customers have become co-producers over the effective lifecycle (Hollebeek et al., 2019).

\subsection{Pre-1990: Develop an online promotional strategy in line with customer gratification} and expectation to build a successful relationship.

Consumerism, which emerged in the 1970s, formed the principle of customers' need for information and pioneered the concept of relationship marketing leading to the period of the 1990s (Bagozzi, 1975). Firms had to anticipate the pre-purchase expectations and gratification of customers to ensure the development of a long-term relationship (Roshwalb, 1956). As customers required information beyond the quality of products, the Internet offered firms the ability to develop a communications strategy that provides comprehensive information on the entire value chain to satisfy broader psychological needs of customers (Hawes, 1987; Markin, 
1979). However, it was challenging for firms to reach customers online due to the lack of personal and physical interaction associated with a traditional store (Christian, 1962). Furthermore, commercial Internet service providers only began to emerge in the very late 1980s, and limited private connections to parts of the Internet by officially commercial entities commenced in a few American cities by late 1989 and 1990. Therefore, during this stage, only a small number of customers were able to access the Internet.

\subsection{0s: Design online systems and networks to provide real-time information and create} a relationship through credibility.

During this period, there was an increase in the number of users 'browsing' the Internet, which became a major source for news and information as an alternative to traditional media and a potential means of targeting target segments in a highly concentrated marketing effort (Tiwana, 1998). However, it was also more challenging for online firms to maintain their market share due to an increase in competition and the emergence of online trading companies (Alba et al., 1997). Thus, to survive in the technology-driven online market, a firm needs to develop sophisticated networks to integrate key stakeholders and provide updated and accurate information to customers. Online relationship building with customers depended on the firm's ability to deliver timely and reliable information on product quality and pricing (Yuan et al., 1998).

\subsection{0s: Create a successful online relationship based on customer knowledge, social networks, and e-WOM.}

This era emerged through the advancement of online technologies and the use of multiple devices by customers enabling uninterrupted connectivity and mobility (Bruner and Kumar, 2005). The customers enjoyed a stronger affiliation with online firms that re-designed their 
online interface to stimulate social interactions (Kulviwat et al., 2009). The online attachment created an opportunity to reach a broader customer base through social influence (Thompson and Arsel, 2004; Brown and Krishna, 2004). Also, the online collaboration between firm and customers enabled the formation of mutual advantage and an increase in social capital through goal congruence (Bart et al., 2005). A firm could develop an online strategy by recognising and rewarding key customers with the potential to influence the behaviour of others through the Internet and social networks (Danaher et al., 2003). A marketing information system and a database are required to facilitate online real-time customer correspondence to ensure the creation of positive e-WOM and a loyal community (Kozinets, 2002).

\subsection{0s: Moving forward with value co-creation and building customer equity through retention and repeat purchase.}

The continuous advancement and complexity of new technologies evoked a higher user interest in online communications and enhanced the use of personal devices to access information (Bartl et al., 2013). Growing access to online information enables customers to express their opinions and ideas on their consumption and experience and communicate with firms in real time (Hollebeek et al., 2019). On the other hand, advanced technologies allow firms to gather a significant amount of customer information and, as a result, be able to develop a good understanding of customer preferences, needs, and wants. This leads to higher collaboration, greater customer power, and a more balanced relationship, which enables a firm to build a loyal customer base and helps develop a core-competence (McColl-Kennedy et al., 2019). Furthermore, it is important to design an appropriate user interface and demonstrate superior service delivery to create value to customers (Punyatoya, 2019), which ultimately results in more repeat purchases and higher lifetime customer value (Dechant et al., 2019). 


\section{Theoretical insights into online relationship marketing}

The theoretical insights pertaining to online relationship marketing are selected considering the significance and influence on the development of an online relationship between the firms and customers (Thaichon et al., 2018). Although many theories can be used to explain online relationship marketing, we specifically focus on six theories (Table 2) that are fundamental principles and most relevant to the stages of the online relationship marketing evolution specified in the previous section. 
Table 2: Theoretical insights into online relationship marketing

\begin{tabular}{|c|c|c|c|c|}
\hline Key Theories & Derived from & Definitions & Key Takeaways & Illus trative Studies \\
\hline $\begin{array}{l}\text { Uses and } \\
\text { gratification } \\
\text { theory }\end{array}$ & $\begin{array}{l}\text { Hornik and Schlinger } \\
\text { (1981) }\end{array}$ & $\begin{array}{l}\text { Uses and gratifications theory indicates } \\
\text { that individual motivation for information } \\
\text { acquisition is determined based on social } \\
\text { and psychological needs (Hornik and } \\
\text { Schlinger, 1981). The user expectations lead } \\
\text { to different patterns of media usage where } \\
\text { customers opt for a medium that satisfy } \\
\text { their unique needs and experience (Simon, } \\
\text { 2017). }\end{array}$ & $\begin{array}{l}\text { A firm needs to develop an interactive online } \\
\text { platform that is simultaneously entertaining } \\
\text { and informative to develop sustainable online } \\
\text { relationship marketing (Abrantes et al., 2013). } \\
\text { A firm should differentiate online strategy to } \\
\text { satisfy customers' needs and wants (Lee et } \\
\text { al., 2013). }\end{array}$ & $\begin{array}{l}\text { Abrantes et al. (2013), Dolan } \\
\text { et al. (2016), Lee et al. (2013), } \\
\text { Lim and Kumar (2017) }\end{array}$ \\
\hline $\begin{array}{l}\text { Signalling } \\
\text { theory }\end{array}$ & $\begin{array}{l}\text { Boulding and } \\
\text { Kirmani (1993) }\end{array}$ & $\begin{array}{l}\text { Signalling theory indicates that buyers and } \\
\text { sellers possess asymmetric information; } \\
\text { therefore, customers use various online } \\
\text { cues to make inferences about a firm and its } \\
\text { offering (Boulding and Kirmani, 1993). }\end{array}$ & $\begin{array}{l}\text { A firm can provide comprehensive } \\
\text { information and different cues such as web } \\
\text { site design, brand alliances, seals of } \\
\text { approval, return policy and privacy } \\
\text { disclosures to facilitate a mutual understating } \\
\text { with potential customers and motivate them } \\
\text { to purchase (Kirmani and Rao, 2000). Online } \\
\text { firms can use signals to separate them from } \\
\text { competitors and attract customers (Bonifield } \\
\text { et al., 2010). }\end{array}$ & $\begin{array}{l}\text { Aiken and Boush (2006), } \\
\text { Akdeniz and Talay (2013), } \\
\text { Bonifield et al. (2010), } \\
\text { Zeithaml et al. (2002) }\end{array}$ \\
\hline $\begin{array}{l}\text { Social influence } \\
\text { theory }\end{array}$ & Kelman (1958) & $\begin{array}{l}\text { Social influence theory proposes that an } \\
\text { individual's attitudes, beliefs and behaviors } \\
\text { are influenced by three theoretical } \\
\text { processes, namely compliance process (i.e. } \\
\text { the anticipation of others to gain reward or } \\
\text { avoid punishment), internalization process } \\
\text { (i.e. influence related to group norms that } \\
\text { match their goals and values) and } \\
\text { identification process (i.e. adoption of a } \\
\text { behaviour to develop or cultivate a good } \\
\text { relationship with a social group) (Kelman, } \\
\text { 1958). }\end{array}$ & $\begin{array}{l}\text { Under social influence, online customer } \\
\text { communities enable a firm to reach a broader } \\
\text { online customer base via generation of } \\
\text { positive e-WOM communication from } \\
\text { satisfied customers (Katona et al., 2011). } \\
\text { However, firms should also pay attention to } \\
\text { social influence created by customers } \\
\text { through online reviews since any negative } \\
\text { ideas or criticism can negatively influence the } \\
\text { relationship with existing and potential } \\
\text { customers (Cheng and Ho, 2015). }\end{array}$ & $\begin{array}{l}\text { Cheng and Ho (2015), Katona } \\
\text { et al. (2011), Kelman (1958), } \\
\text { Sridhar and Srinivasan (2012), } \\
\text { Wang et al. (2016) }\end{array}$ \\
\hline $\begin{array}{l}\text { Social capital } \\
\text { theory }\end{array}$ & Coleman (1990) & $\begin{array}{l}\text { Social capital refers to the resources derived } \\
\text { from a network of relationships developed } \\
\text { over a period of time such as structural (e.g. } \\
\text { network ties), cognitive (e.g. shared } \\
\text { language and understanding), and relational } \\
\text { (e.g. friendship, relational norms, } \\
\text { obligations and mutual identification) } \\
\text { dimensions (Filieri et al., 2014). }\end{array}$ & $\begin{array}{l}\text { Social capital theory identifies that stronger } \\
\text { relationships between a firm and its } \\
\text { customers leads higher levels of resources } \\
\text { (Hartmann and Herb, 2015). A firm need to } \\
\text { leverage social capital such as the power of } \\
\text { the customers' network (Qu et al., 2013). } \\
\text { Furthermore, the willingness to solve } \\
\text { customer problems and share resources } \\
\text { through online collaboration can facilitate the } \\
\text { creation of social capital to enhance customer } \\
\text { loyalty and long-term retention (Mathwick et } \\
\text { al., 2007). }\end{array}$ & $\begin{array}{l}\text { de Kervenoael et al. (2009), } \\
\text { Huang (2016), Mathwick et } \\
\text { al., (2008), Qu et al. (2013) }\end{array}$ \\
\hline $\begin{array}{l}\text { Value co- } \\
\text { creation }\end{array}$ & $\begin{array}{l}\text { Vargo and Lusch } \\
\text { (2004) }\end{array}$ & $\begin{array}{l}\text { Value co-creation signify a shift from } \\
\text { product dominant logic to service dominant } \\
\text { logic, positioning the customer as a co- } \\
\text { producer of value (Vargo and Lusch, 2004). } \\
\text { Customers are not a passive receiver of } \\
\text { value but value is co-created between the } \\
\text { firm and its active customer through } \\
\text { interactions (Payne et al., 2008) }\end{array}$ & $\begin{array}{l}\text { The online environment provides firms with } \\
\text { an opportunity use multiple platforms } \\
\text { including websites, social media and related } \\
\text { networks to effectively interact with } \\
\text { customers, faciliate the exchange of } \\
\text { resources and enable value co-creation } \\
\text { process (Abeza et al., 2018). }\end{array}$ & $\begin{array}{l}\text { Abeza et al. (2018), Chen et } \\
\text { al. (2018), Quach and } \\
\text { Thaichon (2017), Zhang et al. } \\
\text { (2018) }\end{array}$ \\
\hline $\begin{array}{l}\text { Customer } \\
\text { equity theory }\end{array}$ & $\begin{array}{l}\text { Hogan et al. (2002), } \\
\text { Rust et al. (2004) }\end{array}$ & $\begin{array}{l}\text { Customer equity theory recognise a } \\
\text { customer as an asset of the firm where a } \\
\text { long-term relationship between the firm and } \\
\text { the customer leading to generating } \\
\text { consistent profit over the effective } \\
\text { economic life of a customer (Hogan et al., } \\
\text { 2002). }\end{array}$ & $\begin{array}{l}\text { Customer equity theory encourages firms to } \\
\text { focus on building a loyal customer base and } \\
\text { emphasise on creating a path for marketing to } \\
\text { be financially accountable on the basis of } \\
\text { financial return over a period of time (Rust et } \\
\text { al., 2004). A firm should identify the total } \\
\text { revenue and profit that can be generated from } \\
\text { existing and prospective customers over the } \\
\text { customer life cycle, and allocate resources } \\
\text { based on optimal customer segmentation } \\
\text { (Benedetto and Kim, 2016). }\end{array}$ & $\begin{array}{l}\text { Jaiswal et al. (2018), Hwang et } \\
\text { al. (2016), Zang et al. (2016) }\end{array}$ \\
\hline
\end{tabular}




\subsection{Uses and Gratification Theory}

The uses and gratifications theory demonstrates that gratifications sought from the media can include diversion, entertainment, and information (O’Donohoe, 1994). These motivations will vary according to the social roles and psychological disposition of individual audience members, such as the desire to enrich social and psychological needs (Hornik and Schlinger, 1981). Therefore, user expectations lead to different patterns of media usage and, as a result, customers tend to select a medium that is capable of delivering the anticipated communication (Simon, 2017). Customers often expect enjoyment and a feeling of connectedness in searching for information online (Lim and Kumar, 2017). In line with this thinking, Calder, Malhouse and Schaedel (2009) reveal that customer participation in discussions and socialisation with other online users via a website can increase the effectiveness of firm-initiated marketing communications. Therefore, online firms need to invest in developing interactive and pleasurable experiences for customers in order to connect with them. They also need to identify the social and cognitive paradigms associated with each target market and develop a unique promotional strategy to position their products or services. In addition, effective communication and information exchange via social media can be used to motivate customers to engage in collaborative communications (Dolan et al., 2016).

\subsection{Signalling Theory}

Signalling theory indicates that customers face an information asymmetry on the entire decision-making process, from evaluating pre-purchase options to post-purchase consumption (Mitra and Fay, 2010). This creates an opportunity for firms to gain a competitive advantage by providing better information quality (Boulding and Kirmani, 1993). Although development of an effective signalling strategy can be challenging due to the unavailability of the tangible signals, which are only associated with physical stores (Katona et al., 2011), different virtual 
informational cues, for example, web site design, brand alliances, seals of approval, return policy, and privacy disclosures can act as signals and may help customers to make inferences about a firm (Akdeniz and Talay, 2013). A convincing online strategy is required to increase customer confidence in receiving and interpreting information and, as a result, developing a positive relationship between a firm and its customers (Akdeniz and Talay, 2013). A firm should carefully design their websites and other online platforms to separate them from competitors and increase credibility and assurance (Aiken and Boush, 2006).

\subsection{Social Influence Theory}

Social influence theory proposes that an individual's attitudes, beliefs, and behaviours are influenced by three theoretical processes, namely compliance process (i.e. the anticipation of others to gain reward or avoid punishment), internalisation process (i.e. influence related to group norms that match their goals and values), and identification process (i.e. adoption of a behaviour to develop or cultivate a good relationship with a social group) (Kelman, 1958). Online communities can benefit from functional and social benefits by collaboration and the sharing of knowledge (Wang et al., 2016). The interactions between various online users can prompt the diffusion of information, generation of novel ideas, and development of a common interest in consumption (Aral, 2011). Under the social influence, online customer communities enable a firm to reach a broader online customer base via the generation of positive e-WOM communication from satisfied customers (Katona et al., 2011). For example, a positive online review by an opinion leader could have a favourable impact on other users and help strengthen the relationship between a firm and a wider community of customers (Sridhar and Srinivasan,

2012). However, firms need to monitor the social influence created by customers in online platforms, such as social media, since any adverse influence can damage the relationships (Cheng and Ho, 2015). 


\subsection{Social Capital Theory}

The social capital theory identifies networks of relationships developed over time as resources (Filieri et al., 2014). Social capital often takes different forms and includes different critical aspects, such as structural (e.g. network ties), cognitive (e.g. shared language and understanding), and relational (e.g. friendship, relational norms, obligations, and mutual identification) dimensions (Huang, 2016). Social capital between buyers and sellers not only can help enhance dyadic relationships, but it can also increase customer involvement. The relationship between the firm and customers can result in collective benefits, including the sharing of tangible and intangible resources such as knowledge and values. Hence, organisations should leverage social capital in their long-term relationships with loyal customers (Huang, 2016). Furthermore, the willingness to solve customer problems and share resources through online collaboration will ensure the creation of social capital to enhance customer loyalty and long-term retention (Mathwick et al., 2007).

\subsection{Value Co-Creation}

Service-dominant logic emphasises the value co-creation process in which customers are coproducers and engage in the exchange of resources (Vargo and Lusch, 2004). Payne et al. (2008) claim that customers are not a passive receiver of value, but value is co-created between the firm and its active customers through interactions. The online environment enables a firm to use multiple platforms to interact with customers and encourage their participation in the value creation process (Abeza et al., 2018). Co-creating value requires firms to engage its customers and captivate and nurture the resources they share during this process, such as feedback and ideas for new product development (Quach and Thaichon, 2017). Firms can also inspire co-creation by developing online visitor communities, social clubs, and brand 
associations (Zhang et al., 2018). Greater value co-creation can lead to a better relationship between firms and customers (Chen et al., 2018).

\subsection{Customer Equity Theory}

Customer equity is defined as "the total of the discounted lifetime values summed over all of the firm's current and potential customers" (Rust et al. 2004, p.110). This inspires firms to focus on building a loyal customer base and ensure decisions are financially accountable on the basis of return on investment over a period of time (Rust et al., 2004). Customer equity theory recognises a customer as an asset of the firm, as a long-term relationship leads to consistent profit over the effective economic life (Hogan et al., 2002). Therefore, a firm should determine the total revenue and profit that can be generated from existing and prospective customers in order to identify key customers and allocate resources based on optimal customer

lifetime value. A firm can segment customers based on online purchases and target stages of the lifecycle and consequently, design differentiated strategies such as providing incremental rewards to loyal customers to build sustainable online relationships (Jaiswal et al., 2018).

\section{Empirical insight into online relationship marketing}

Table 3 presents the major areas in empirical online relationship marketing studies, namely, relationship quality, relationship development, dynamic value creation and destruction, and technologies in online relationship marketing. 
Table 3: Empirical insights into online relationship marketing

\begin{tabular}{|c|c|c|c|c|}
\hline Key Constructs & Theory & $\begin{array}{c}\text { Methodology/ Res earch } \\
\text { Context }\end{array}$ & Key Findings & Illus trative Study \\
\hline \multicolumn{5}{|l|}{ Relationship quality } \\
\hline Online trust influence & Signalling theory & $\begin{array}{l}\text { Survey } \\
\text { Sampling frame is } \\
\text { National Family } \\
\text { Opinion's online panel } \\
\text { across different } \\
\text { industries (Websites) }\end{array}$ & $\begin{array}{l}\text { It was found that privacy and order fulfillment are the most influential } \\
\text { determinants of trust for sites in with high information risk and } \\
\text { involvement whereas navigation has the strongest influence on trust } \\
\text { for information-intensive sites. In addition, trust affects behavioural } \\
\text { intent such as willingness to click through, leaving or resuming a } \\
\text { site, sending e-mail messages, downloading trials, and placing an } \\
\text { order. }\end{array}$ & Bart et al. (2005) \\
\hline $\begin{array}{l}\text { Social media } \\
\text { involvement; loyalty }\end{array}$ & $\begin{array}{l}\text { Social exchange } \\
\text { theory/social capital } \\
\text { theory }\end{array}$ & $\begin{array}{l}\text { Field experiment } \\
\text { Selected program } \\
\text { members participated in } \\
\text { a Facebook group }\end{array}$ & $\begin{array}{l}\text { The participants who gathered loyalty points through their social } \\
\text { media engagement had significantly higher level of attitudinal loyalty } \\
\text { towards the loyalty program and the company than that of the } \\
\text { loyalty members who collected points solely through transactions. }\end{array}$ & $\begin{array}{l}\text { Rehnen et al. } \\
(2017)\end{array}$ \\
\hline $\begin{array}{l}\text { Commitment; value; } \\
\text { behavioural loyalty }\end{array}$ & Social identity theory & $\begin{array}{l}\text { Survey } \\
\text { Members of online } \\
\text { group buying websites } \\
\text { in Taiwan }\end{array}$ & $\begin{array}{l}\text { Perceived value such as scheme value, hedonic value and social } \\
\text { value influence affective commitment which in turn have a positive } \\
\text { impact on customer online loyalty, namely intention to revisit and } \\
\text { purchase more. }\end{array}$ & Chiu et al. (2018) \\
\hline $\begin{array}{l}\text { Commitment; trust; } \\
\text { loyalty; social media } \\
\text { context }\end{array}$ & $\begin{array}{l}\text { Commitment-trust } \\
\text { theory; social capital } \\
\text { theory }\end{array}$ & $\begin{array}{l}\text { Survey } \\
\text { Online brand } \\
\text { community members in } \\
\text { India }\end{array}$ & $\begin{array}{l}\text { Commitment to the customer-brand relationship is positively } \\
\text { associated to the brand trust. Both trust and commitment in online } \\
\text { brand communities are determinants of customer loyalty. }\end{array}$ & Jain et al. (2018) \\
\hline $\begin{array}{l}\text { Satisfaction; loyalty; } \\
\text { trust; value }\end{array}$ & & $\begin{array}{l}\text { Survey } \\
\text { E-retailing customers }\end{array}$ & $\begin{array}{l}\text { The study confirms that e-satisfaction has an impact on e-loyalty. } \\
\text { This relationship can be impacted by (a) consumers' individual level } \\
\text { factors including convenience motivation, purchase size and inertia, } \\
\text { and (b) firms' business level factors such as trust and perceived } \\
\text { value. }\end{array}$ & $\begin{array}{l}\text { Anderson and } \\
\text { Srinivasan (2003) }\end{array}$ \\
\hline \multicolumn{5}{|l|}{ Relationship development } \\
\hline$\underline{\text { Firm incentives }}$ & & & & \\
\hline $\begin{array}{l}\text { Firm incentives; online } \\
\text { referral behaviour }\end{array}$ & Customer equity theory & $\begin{array}{l}\text { Field experiment } \\
\text { Members of an online } \\
\text { shopping mall, Ebates. }\end{array}$ & $\begin{array}{l}\text { Higher incentives can increase the number of sent referral } \\
\text { invitations, new members sign-ups and recruitment of new } \\
\text { customers. The difference between incentives for senders and } \\
\text { receivers have an impact on the e-referral rates. It is suggested that } \\
\text { higher incentives for senders will improve the outcomes. }\end{array}$ & $\begin{array}{l}\text { Ahrens et al. } \\
\text { (2013) }\end{array}$ \\
\hline $\begin{array}{l}\text { Social media strategy; } \\
\text { social customer } \\
\text { relationship } \\
\text { management; firm } \\
\text { performance }\end{array}$ & $\begin{array}{l}\text { Dynamic capabilities } \\
\text { theory; the resource- } \\
\text { based view (RBV); } \\
\text { value co-creation } \\
\text { theory }\end{array}$ & $\begin{array}{l}\text { Stochastic frontier } \\
\text { estimation } \\
\text { Social media (Facebook) } \\
\text { data and COMPUSTAT } \\
\text { North America, and } \\
\text { Global Fundamentals } \\
\text { annual databases }\end{array}$ & $\begin{array}{l}\text { Integrating social media into marketing strategies is vital to } \\
\text { strengthen customer engagement and firm performance. Social media } \\
\text { can assist a firm to establish a new form of customer relationship } \\
\text { management (CRM), named social customer relationship } \\
\text { management (SCRM), and have an impact on firm performance. }\end{array}$ & $\begin{array}{l}\text { Wang and Kim } \\
\text { (2017) }\end{array}$ \\
\hline $\begin{array}{l}\text { Personalisation; } \\
\text { customers' } \\
\text { heterogeneous needs }\end{array}$ & $\begin{array}{l}\text { Social capital theory; } \\
\text { lead-users theory }\end{array}$ & $\begin{array}{l}\text { Online survey } \\
\text { Customers of Tencent, a } \\
\text { major internet service } \\
\text { provider in China }\end{array}$ & $\begin{array}{l}\text { Firms provide personalised webpages, virtual products and services, } \\
\text { as well as allocate customised supporting resources to the customers } \\
\text { in order to meet customers' heterogeneous needs. }\end{array}$ & $\begin{array}{l}\text { Wang and } \mathrm{Li} \\
\text { (2013) }\end{array}$ \\
\hline $\begin{array}{l}\text { Personalised } \\
\text { recommender systems } \\
\text { (PRS); customer } \\
\text { satisfaction; purchase } \\
\text { intention }\end{array}$ & $\begin{array}{l}\text { Social cognitive } \\
\text { theory; social } \\
\text { interaction theory }\end{array}$ & $\begin{array}{l}\text { Web-based experiments } \\
\text { Apps and descriptions } \\
\text { from Podgate } \\
\text { (www.podgate.com), an } \\
\text { online community } \\
\text { in South Korea focused } \\
\text { on smartphone apps }\end{array}$ & $\begin{array}{l}\text { The findings indicate that social interactions including self } \\
\text { referencing and social presence significantly increase the perceived } \\
\text { accuracy and novelty of personalised recommender systems which } \\
\text { in turn have a positive influence on user satisfaction as well as } \\
\text { purchase intention. }\end{array}$ & Choi et al. (2017) \\
\hline $\begin{array}{l}\text { Personalisation; sense of } \\
\text { control }\end{array}$ & $\begin{array}{l}\text { Interactive media } \\
\text { effects (TIME) theory }\end{array}$ & $\begin{array}{l}\text { Experiment/Online } \\
\text { survey } \\
\text { Movie recommendation } \\
\text { system }\end{array}$ & $\begin{array}{l}\text { Offering customers the ability to customize their privacy settings at } \\
\text { the outset improve user experience in the presence of both reactive } \\
\text { personalization (i.e., enabling customers to show their preferences } \\
\text { before receiving personalized content) and proactive personalization } \\
\text { (i.e., automatically fetching it to them). Also, users with relatively } \\
\text { less negative privacy experience does not experience much } \\
\text { difference between proactive and reactive personalization in } \\
\text { triggering their privacy concerns. }\end{array}$ & $\begin{array}{l}\text { Zhang and Sundar } \\
\text { (2019) }\end{array}$ \\
\hline
\end{tabular}


Table 3: Empirical insights into online relationship marketing (continual)

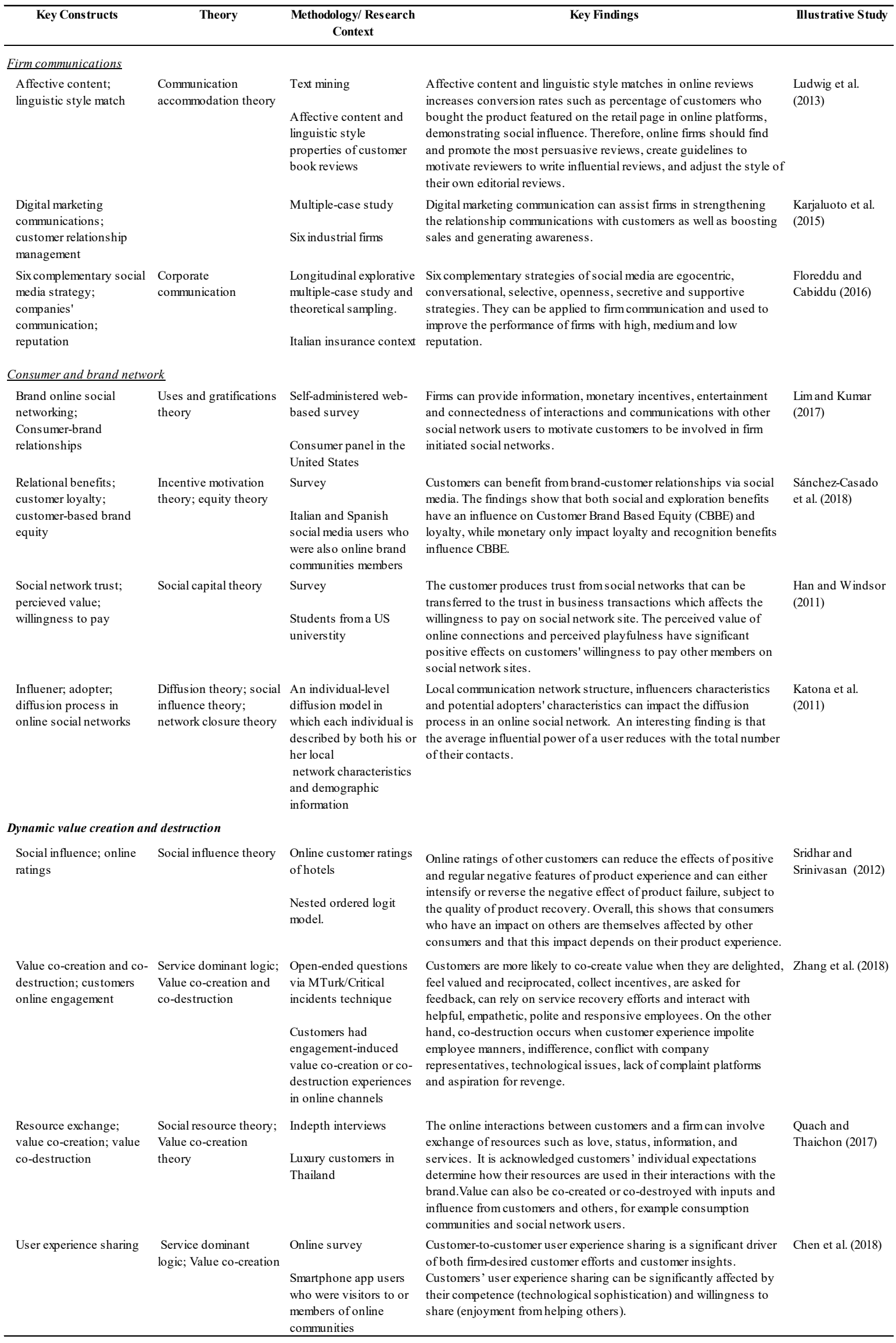


Table 3: Empirical insights into online relationship marketing (continual)

\begin{tabular}{|c|c|c|c|c|}
\hline Key Cons tructs & Theory & $\begin{array}{c}\text { Methodology/ Research } \\
\text { Context }\end{array}$ & Key Findings & Illustrative Study \\
\hline \multicolumn{5}{|c|}{ Application of new technologies } \\
\hline \multicolumn{5}{|c|}{ Technologies facilitating new business models } \\
\hline $\begin{array}{l}\text { Intelligent } \\
\text { recommendation system; } \\
\text { data mining technology; } \\
\text { cross-reference usage } \\
\text { patterns }\end{array}$ & Value creation & $\begin{array}{l}\text { Case study } \\
\text { Netflix and Spotify }\end{array}$ & $\begin{array}{l}\text { The intelligent recommendation system highlights the importance of } \\
\text { unique and suitable recommendations to customers through cross- } \\
\text { referencing usage patterns across all users instead of relying on past } \\
\text { consumption behaviour of an individual customer. This can be done } \\
\text { by using the power of data mining technology. }\end{array}$ & $\begin{array}{l}\text { Rayna and } \\
\text { Striukova (2016) }\end{array}$ \\
\hline $\begin{array}{l}\text { The triadic business } \\
\text { model (T model) }\end{array}$ & $\begin{array}{l}\text { Resource dependency } \\
\text { theory }\end{array}$ & $\begin{array}{l}\text { Case study } \\
\text { Empirical examples from } \\
\text { Uber }\end{array}$ & $\begin{array}{l}\text { The new business model, T-model, aiming at creating value by } \\
\text { facilitating exchanges and transactions among two or more parties } \\
\text { via a platform. The T-model is also considered representing two- } \\
\text { sided markets. }\end{array}$ & $\begin{array}{l}\text { Andreassen et al. } \\
(2018)\end{array}$ \\
\hline \multicolumn{5}{|c|}{ Technologies facilitating interactions and communications } \\
\hline $\begin{array}{l}\text { Social listening; Big data; } \\
\text { User generated content }\end{array}$ & $\begin{array}{l}\text { Prospect theory; } \\
\text { Outside-in marketing }\end{array}$ & $\begin{array}{l}\text { Multivariate GARCH } \\
\text { model; sentiment } \\
\text { analysis } \\
\text { The first study use data } \\
\text { focusing on Apple's } \\
\text { iPhone brand. The } \\
\text { second study use data } \\
\text { from } 4 \text { airlines: Delta, } \\
\text { JetBlue, Southwest and } \\
\text { United Airlines. }\end{array}$ & $\begin{array}{l}\text { Using the outside-in perspective, the study shows that engaging } \\
\text { from an outside-in perspective, i.e., by listening in social media can } \\
\text { enable firms to gain a competitive advantage. The study shows } \\
\text { significant volatility spillovers between the growth rates of user- } \\
\text { generated content and stock returns. }\end{array}$ & $\begin{array}{l}\text { van Dieijena et al. } \\
2019\end{array}$ \\
\hline $\begin{array}{l}\text { Data-driven online } \\
\text { communication; } \\
\text { Intelligent agent } \\
\text { technologies (IATs) }\end{array}$ & $\begin{array}{l}\text { Customer orientation; } \\
\text { value creation }\end{array}$ & $\begin{array}{l}\text { Grounded } \\
\text { theory/interviews } \\
\text { Managers from } 50 \\
\text { companies in } 22 \\
\text { industries }\end{array}$ & $\begin{array}{l}\text { Intelligent agent technologies (IATs) are "computational systems } \\
\text { that inhabit a complex dynamic environment and continuously } \\
\text { perform marketing functions such as (a) dynamic scanning of the } \\
\text { environment and market factors including competitors and } \\
\text { customers, and firm actions impacting the marketing mix; (b) } \\
\text { collaborating and interacting to interpret perceptions, analyzing, } \\
\text { learning and drawing inferences to solve problems; and (c) } \\
\text { implementing customer-focused strategies that create value for the } \\
\text { customers and the firm within the boundaries of trustworthiness and } \\
\text { policy". The usage of data-driven online communication and } \\
\text { intelligent agent technologies can improve customers online } \\
\text { experiences. }\end{array}$ & Kumar et al. (2017) \\
\hline $\begin{array}{l}\text { Artificial Intelligence; } \\
\text { innovation, multiple actor } \\
\text { interactions }\end{array}$ & Value co-creation & $\begin{array}{l}\text { Case study (open data } \\
\text { coding and thematic } \\
\text { analysis) } \\
\text { IBM }\end{array}$ & $\begin{array}{l}\text { This article highlights the value innovation faciliated by Artificial } \\
\text { Intelligence (AI). The findings show that multiple actors can interact, } \\
\text { cooperate, learn and find new ways to perform and serve others } \\
\text { better and co-create value through AI. In general, AI can be used to } \\
\text { promote networking and sharing practices for value creating and } \\
\text { innovating. }\end{array}$ & $\begin{array}{l}\text { Russo-Spena, } \\
\text { Mele and Marzullo } \\
\text { (2018) }\end{array}$ \\
\hline $\begin{array}{l}\text { Text mininh; customer } \\
\text { textual feedback; } \\
\text { resources }\end{array}$ & Value cocreation & $\begin{array}{l}\text { Case study } \\
\text { The car park and } \\
\text { transfer service in U.K. }\end{array}$ & $\begin{array}{l}\text { The study proposes a framework to analyse customer feedback by } \\
\text { covering three key components of the value cocreation process: } \\
\text { activities, resources, and context. This framework facilitates use of } \\
\text { text mining technology for analysis of customer textual feedback that } \\
\text { enables firm to evaluate the influence of interaction processes on } \\
\text { customer experiences. Text mining technologies help firms be able to } \\
\text { timely assess customer experience feedback which is a condition for } \\
\text { successful cocreation processes in aan online environment. }\end{array}$ & Ordenes et al. 2014 \\
\hline
\end{tabular}

\subsection{Relationship quality in online relationship marketing}

It is critical that firms are able to develop and maintain the quality of their online relationship with buyers in order to increase customer lifetime value. Online relationship quality is widely recognised as a high-level concept that encompasses trust, commitment, and customer satisfaction (Walsh et al., 2010). Trust, defined as "a willingness to rely on an exchange partner in whom one has confidence" (Moorman, Deshpande, and Zaltman, 1993, p. 90), has assumed 
an essential role in establishing and maintaining a long-term relationship between sellers and customers. It is often more challenging to establish online trust due to the nature of the virtual environment, which lacks a human touch. According to signalling theory, complete information and virtual cues such as product descriptions, website design, and pricing can be used to establish trust. Also, online firms need to be able to address customer privacy concerns, as well as increase the quality of online communications and the level of security in online transactions in order to build trust (Bart et al., 2005). Once trust is established, customers are more likely to be more committed to e-commerce and online firms. In other words, they develop "an enduring desire to maintain a valued relationship" (Moorman, Deshpande, and Zaltman, 1993). Customer satisfaction is another determinant of trust and commitment and is determined by online performance, such as website quality and online customer service (Jain et al., 2018). Firms that can build a high-quality relationship with customers can benefit from customer loyalty and engagement.

Loyal customers reward firms by an increase in repurchase intention, as well as a share of wallet. Also, they have a higher preference for the firm and are more likely to engage with firms, such as through participation in firm-initiated social media activities, thereby increasing customer engagement value. Customer engagement value is conceptualised as the mechanism of how a customer adds value to the firm through direct and/or indirect contribution (Pansari and Kumar, 2017). Apart from customer purchases contributing directly to firm value, there are three types of indirect contributions. The first one is customer-incentivised referrals, such as email referrals, which are very effective in recruiting new customers who otherwise cannot be reached via traditional marketing channels (Kumar, 2018). Furthermore, customers can indirectly contribute to firms through their social media influence in a social network, which can also result in a ripple effect and extend to a larger group of customers (Hogan et al., 2002). 
Finally, another indirect contribution to firm performance is customer feedback and suggestions to the firm populated via online platforms.

\subsection{Relationship development}

In order to achieve high online relationship quality, firms need to invest in relationship development. According to customer equity theory, this can be done through the facilitation of online interactions and communication with customers, and the establishment of customerbrand and customer-customer networks. For example, firms can offer incentives such as loyalty programs, lucky draws, and price promotions to encourage customers to participate online. In this process, social media plays an important role in helping firms establish an extension of customer relationship management (CRM), namely social CRM (Wang and Kim, 2017). Social $\mathrm{CRM}$ is defined as "the integration of traditional customer-facing activities, including processes, systems, and technologies with emergent social media applications, to engage customers in collaborative conversations and enhance customer relationships" (Trainor 2014, p. 321).

One of the social CRM capabilities is the development of online content in social media, which demonstrates the ability to "generating, integrating, and responding to information obtained from customer interactions that are facilitated by social media technologies" (Trainor et al. 2014, p. 271). Effective marketing communication via social media assists firms in strengthening their relationship with customers, boosting sales, generating awareness, and improving the firm's reputation (Karjaluoto et al., 2015; Floreddu and Cabiddu, 2016). Furthermore, Ludwig et al. (2013) suggest that affective content and linguistic style matching in online reviews increases conversion rates, such as percentage of customers who purchase the product featured on the retail page in online platforms, demonstrating social influence. Therefore, online firms should find and promote the most persuasive reviews, create guidelines 
to motivate reviewers to write influential reviews, and adjust the style of their own editorial reviews. On the other hand, online CRM via social media can also involve negative electronic word-of-mouth (eWOM) which can have a detrimental effect on brand-customer relationship. Firms need to constantly monitor online conversations on social media and employ crisis management and corporate communications strategy to mitigate problems caused by negative eWOM, for example, ensuring timely response and effective use of brand advocates.

On the other hand, firms also invest in personalisation in order to address customers' heterogeneous needs (Wang and Li, 2013), for example, targeted advertising, personalised webpages, and individualised supporting resources to the customers. In addition, the emergence of online personalised recommendation systems allows companies to use customers' data to understand their preferences and provide recommendations that match individual needs and wants (Choi et al., 2017). Online personalisation helps to ensure that customers have positive experiences and contributes to the development of the overall firmcustomer relationship (Zhang and Sundar, 2019).

\subsection{Dynamic value creation and destruction}

Drawing on service dominant logic, customers can be part of both value co-creation and codestruction processes in their interactions with a firm. Value co-creation and co-destruction are two sides of interactive value formation that can occur at the same time (Smith, 2013). While customers value co-creators during online interaction, they can also be valued co-destructors if the customer experiences resource misuse and consequently loss of well-being (Quach and Thaichon, 2017). Firm investment marketing communications and brand social networks provide customers with opportunities to participate in the value co-creation process by sharing their resources, such as social capital, knowledge, information, status, love, and emotions (Quach and Thaichon, 2017; Zhang et al., 2016). For example, customers engage in dialogues 
with a brand, get involved in innovation, and share their experience via online reviews, which increases the level of co-created value, thereby leading to positive outcomes (Chen et al., 2018).

The online value-cocreation process is more complicated than the offline environment, as online interactions, especially in social media, not only happen between customers and the brand, but they also involve other participants; hence, the value can be co-created or codestructed depending on inputs and influence of customers and other network users (Quach and Thaichon, 2017). In addition, when customers are required to use a high level of effort and/or a large amount of resources to participate in the interaction process, this can lead to a negative effect on customers' value perceptions and can be exhibited through customers' unfavourable thoughts, feelings, and behaviours toward the brand during interactions (Hollebeek and Chen, 2014). In the context of an online brand community, social influence can amplify the experience of co-destructed values, leading to negative spillover effects, and result in customers' anti-brand behaviours, for example, brand boycott and negative comments that further reduce the perceived value that other network users can receive from the firm (Bowden et al., 2017).

\subsection{Online technologies}

Technologies have been an essential component of online relationship marketing, facilitating online value co-creation and relationship development, which in turn improve relationship quality. For instance, the intelligent recommendation system enabled by powerful data mining and machine learning suggests options that match customers' preferences. Firms, such as Netflix, have done this through cross-referencing usage patterns across all users instead of simply relying on a customer's past consumption (Reyna and Striukova, 2016). Furthermore, the Internet and advances in logistical systems have enabled a new business model, T-model, aimed at creating value by facilitating exchanges and transactions among two or more parties 
via a platform (Andreassen et al., 2018). The T-model is also considered to represent peer-topeer markets and is particularly popular in the sharing economy. Firms, such as Uber and Airbnb, offer assets, for example, as well as accommodation or tools when available, or labour (e.g., free time) for buyers to use, in order to obtain a fee or additional resource (Andreassen et al., 2018).

Information technology, such as Big Data, machine learning, and artificial intelligence, is another important force in online relationship marketing. In particular, Big Data is central to the business revolution, especially in predictive analysis and personalisation (Rust and Huang, 2014; Wang and Kim, 2017). Firms should take advantage of the availability of customer data via online platforms, such as social media and websites, to better understand customers and effectively respond to customers' preferences. It is recommended that firms invest in innovative capabilities to handle Big Data, such as social listening techniques, text analytics, photo and video analytics, and location-based data that uses Wi-Fi networks and retail in-store beacons, all of which could improve a firm's knowledge of how consumers experience particular events (Lemon and Verhoef, 2016). Overall, previous research shows that datadriven online communication and interactions can improve customers' online experiences (Kumar et al., 2017).

\section{Conclusions and future research directions}

This study has provided an up-to-date systematic review of the literature on key aspects of online relationships. As indicated in previous sections, online relationships have evolved to a new dynamic stage that involves numerous changes, especially due to constant innovation. New technologies have brought both opportunities and challenges for online retailers. There are some key areas that future research could explore (Figure 1). 


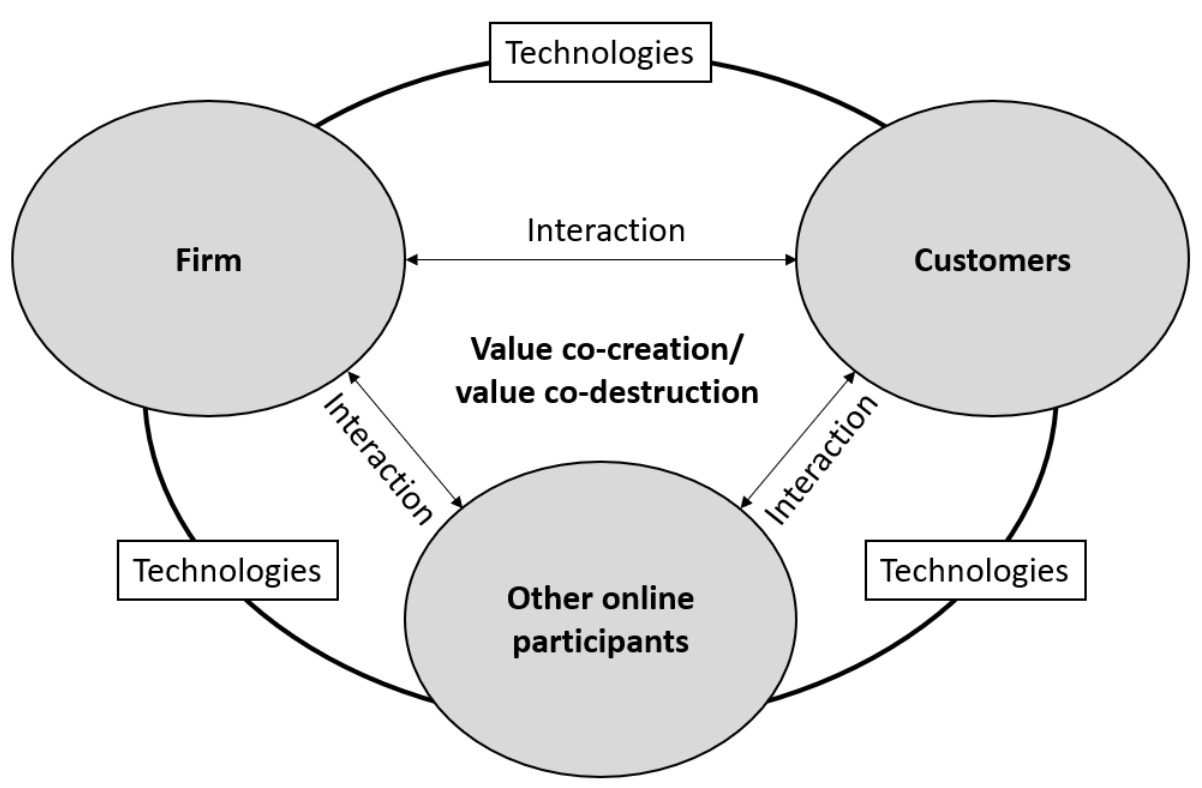

Figure 1: A framework for future research directions

- Multilayers of online communications and interactions. Customers have become coproducers in the value co-creation process with firms. However, the service system in which this process occurs is dynamic and involves networks of other providers, customers, partners, and stakeholders (e.g., Quach and Thaichon, 2017; Vargo and Lusch, 2011). Recently, firms have increasingly used influencer marketing as part of their communications with customers (Jin, Muqaddam, and Ryu, 2019). This has resulted in complexity and challenges in managing firm communications, for example, the characteristics of the influencers (such as opinion leaders), the fit between the influencers and the firm, and the perceptions of customers of the firm. Furthermore, it is increasingly harder to measure the effectiveness of influencer marketing due to the invisible side of sharing called "dark social", which refers to technology-enabled but essentially untraceable methods of social sharing, such as email and private messaging platforms (Martin and Hutchinson, 2018). In line with influencer marketing, the use of seeded marketing campaigns which select a certain number of customers to act as seed agents to generate buzz about a product, brand or company, has also become 
increasingly popular. However, extant research found mixed effects of this marketing tools in relation to other forms of promotional mix and activities. Future research could delve into different layers of interactions and investigate their inter-relationships.

- The dark side of online communications: The use of Big Data has led to better segmentation, targeting, and personalisation. However, this results in greater levels of privacy concerns. Personalised advertising in microtargeting is considered "weaponised ad technology designed for consumer products and services," said Sarah Golding, the president of the Institute of Practitioners in Advertising, an industry organisation in Britain (Singer, 2018). Furthermore, recent information breaches, such as the Cambridge Analytica data scandal, can increase the level of concerns. Customers are more cautious about privacy infringement and data vulnerability, which could lead to value destruction in firm-customer online interactions. Therefore, it is critical to find and deal with the tension between information use and privacy concerns.

- Technologies and platforms: There are many new technologies, such as mixed reality, big data, and artificial intelligence, that have changed how online relationship marketing works. Big Data and machine learning allow companies to leverage new services and provide better and more personalised engagement opportunities for customers (Kunz et al., 2017). For example, a firm can perform data mining (Ordenes et al., 2014) for real-time monitoring of customer sentiment related to their brands, product, services, customers, activities, and resources. Furthermore, blockchain technologies and their application in firm communications, such as programmatic advertising and brand protection against counterfeit (Kumar, 2018), are another fruitful area for research. 


\section{References}

Abeza, G., O’Reilly, N., Finch, D., Séguin, B. and Nadeau, J. (2018), “The role of social media in the co-creation of value in relationship marketing: a multi-domain study", Journal of Strategic Marketing, pp.1-22.

Achrol, R.S. and Kotler, P. (1999), "Marketing in the Network Economy", Journal of Marketing, Vol. 63 No.1, pp. 146-163.

Aiken, K.D. and Boush, D.M. (2006), "Trustmarks, objective-source ratings, and implied investments in advertising: investigating online trust and the context-specific nature of internet signals", Journal of the Academy of Marketing Science, Vol. 34 No. 3, pp.308323.

Akdeniz, M.B. and Talay, M.B. (2013), "Cultural variations in the use of marketing signals: A multilevel analysis of the motion picture industry", Journal of the Academy of Marketing Science, Vol. 41 No. 5, pp.601-624.

Alba, J., Lynch, J., Weitz, B., Janiszewski, C., Lutz, R., Sawyer, A. and Wood, S. (1997), "Interactive Home Shopping: Consumer, Retailer, and Manufacturer Incentives to Participate in Electronic Marketplaces”, Journal of Marketing, Vol. 61 No. 3, pp. 3853.

Anderson, R. E., and Srinivasan, S. S. (2003). "E-satisfaction and e-loyalty: A contingency framework". Psychology and marketing, Vol. 20 No. 2, pp. 123-138.

Andreassen, T. W., Lervik-Olsen, L., Snyder, H., Van Riel, A. C. R., Sweeney, J. C., and Van Vaerenbergh, Y. (2018). "Business model innovation and value-creation: The triadic way". Journal of Service Management, Vol. 29 No.5, pp.883-906.

Aral, S., (2011), “Identifying social influence: A comment on opinion leadership and social contagion in new product diffusion”, Marketing Science, Vol. 30 No. 2, pp.217-223. 
Bagozzi, R.P. (1975), “Marketing as exchange”, Journal of Marketing, Vol. 39 No. 4, pp.3239.

Bart, Y., Shankar, V., Sultan, F. and Urban, G.L. (2005), “Are the Drivers and Role of Online Trust the Same for All Web Sites and Consumers? A Large-Scale Exploratory Empirical Study", Journal of Marketing, Vol. 69 No. 4, pp. 133-152.

Bartl, C., Gouthier, M.H. and Lenker, M. (2013), "Delighting consumers click by click: antecedents and effects of delight online", Journal of Service Research, Vol. 16 No. 3, pp.386-399.

Bialaszewski, D. and Giallourakis, M. (1985), "Perceived communication skills and resultant trust perceptions within the channel of distribution", Journal of the Academy of Marketing Science, Vol.13 No.2, pp. 206-217.

Boulding, W. and Kirmani, A. (1993), "A consumer-side experimental examination of signalling theory: do consumers perceive warranties as signals of quality?", Journal of consumer research, Vol. 20 No. 1, pp.111-123.

Bowden, J. L. H., Conduit, J., Hollebeek, L. D., Luoma-Aho, V., and Solem, B. A. (2017). "Engagement valence duality and spillover effects in online brand communities". Journal of Service Theory and Practice, Vol. 27 No. 4, pp. 877-897.

Brown, C.L. and Krishna, A. (2004), “The skeptical shopper: A metacognitive account for the effects of default options on choice", Journal of consumer research, Vol. 31 No.3, pp.529-539.

Bruner II, G.C. and Kumar, A. (2005), "Explaining consumer acceptance of handheld internet devices", Journal of Business Research, Vol. 58 No. 5, pp.553-558.

Burke, R.R. (1997), “Do you see what I see? The future of virtual shopping”, Journal of the Academy of Marketing Science, Vol. 25 No. 4, pp.352-360. 
Chen, T., Drennan, J., Andrews, L. and Hollebeek, L.D. (2018), "User experience sharing: Understanding customer initiation of value co-creation in online communities", European Journal of Marketing, Vol. 52 No. 6, pp.1154-1184.

Cheng, Y.H. and Ho, H.Y. (2015), "Social influence's impact on reader perceptions of online reviews", Journal of Business Research, Vol. 68 No. 4, pp.883-887.

Choi, J., Lee, H., and Kim, H. (2017). "Examining the effects of personalized app recommender systems on purchase intention: A self and social-interaction perspective”. Journal of Electronic Commerce Research, Vol. 18 No. 1, pp.73-102.

Christian, R.C. (1962), “The computer and the marketing man”, Journal of Marketing, Vol.26 No.3, pp.79-82.

Danaher, P.J., Wilson, I.W. and Davis, R.A. (2003), “A comparison of online and offline consumer brand loyalty", Marketing Science, Vol. 22 No. 4, pp. 461-476.

de Kervenoael, R., Aykac, D.S.O. and Palmer, M. (2009), "Online social capital: Understanding e-impulse buying in practice", Journal of retailing and consumer services, Vol.16 No. 4, pp. 320-328.

Dechant, A., Spann, M. and Becker, J.U. (2019), "Positive customer churn: An application to online dating", Journal of Service Research, Vol. 22 No. 1, pp. 90-100.

Dholakia, U.M., Blazevic, V., Wiertz, C. and Algesheimer, R. (2009), “Communal service delivery: how customers benefit from participation in firm-hosted virtual P3 communities", Journal of Service Research, Vol. 12 No. 2, pp.208-226.

Di Benedetto, C.A. and Kim, K.H. (2016), "Customer equity and value management of global brands", Journal of Business Research, Vol. 69 No. 9, pp. 3721-3724.

Dixit, S., Badgaiyan, A.J. and Khare, A. (2019), “An integrated model for predicting consumer's intention to write online reviews", Journal of Retailing and Consumer Services, Vol. 46 No.1, pp.112-120. 
Dolan, R., Conduit, J., Fahy, J. and Goodman, S. (2016), "Social media engagement behaviour: a uses and gratifications perspective”, Journal of Strategic Marketing, Vol. 24 No. 3/4, pp. 261-277.

Filieri, R., McNally, R.C., O'Dwyer, M. and O'Malley, L. (2014), “Structural social capital evolution and knowledge transfer: Evidence from an Irish pharmaceutical network", Industrial Marketing Management, Vol. 43 No. 3, pp.429-440.

Firdaus, A., and Kanyan, A. (2014), "Managing relationship marketing in the food service industry", Marketing Intelligence \& Planning, Vol. 32 No. 3, pp. 293-310.

Floreddu, P. B., and Cabiddu, F. (2016). "Social media communication strategies". Journal of Services Marketing, Vol. 30 No. 5, pp.490-503.

Gong, T. (2018). "Customer brand engagement behavior in online brand communities". Journal of Services Marketing, Vol. 32 No. 3, pp. 286-299.

Han, B., and Windsor, J. (2011). “User's willingness to pay on social network sites”. Journal of Computer Information Systems, Vol. 51 No. 4, pp.31-40.

Hart, C., Doherty, N. and Ellis-Chadwick, F. (2000), "Retailer adoption of the InternetImplications for retail marketing”, European Journal of Marketing, Vol. 34 No.8, pp.954-974.

Hartmann, E. and Herb, S. (2015), "Interconnectedness of actor bonds in service triads-a social capital perspective", Industrial Marketing Management, Vol. 44, pp.154-165.

Hawes, D.K. (1987), "The Role of Marketing in Facilitating the Diffusion of Microcomputers and 'The Information Society", Journal of the Academy of Marketing Science, Vol.15 No 2, pp.83-90.

Herbig, P.A. and Milewicz, J. (1995), “The impact of marketing signals on strategic decisionmaking ability and profitability", Marketing Intelligence \& Planning, Vol. 13 No.7, pp.37-46. 
Hogan, J.E., Lemon, K.N. and Rust, R.T. (2002), Customer equity management: Charting new directions for the future of marketing. Journal of service Research, 5(1), pp.4-12.

Hollebeek, L., and Chen, T. (2014). "Exploring positively-versus negatively-Balenced brand engagement: a conceptual model”. Journal of Product and Brand Management, Vol. 23 No. 1, pp. 62-74.

Hollebeek, L.D., Srivastava, R.K. and Chen, T. (2019), "SD logic-informed customer engagement: integrative framework, revised fundamental propositions, and application to CRM", Journal of the Academy of Marketing Science, Vol. 47 No 1, pp.161-185.

Hornik, J. and Schlinger, M.J. (1981), “Allocation of time to the mass media”, Journal of Consumer Research, Vol. 7 No. 4, pp.343-355.

Huang, L.T. (2016), "Flow and social capital theory in online impulse buying", Journal of Business Research, Vol. 69 No. 6, pp.2277-2283.

Hwang, J.H., Chung, J., Kim, J.W., Lee, D. and Yoo, W.S. (2016), “Antecedents to loyalty point redemption: Implications for customer equity management”, Journal of Business Research, Vol. 69 No. 9, pp.3731-3739.

Jain, N. K., Kamboj, S., Kumar, V. and Rahman, Z. (2018), “Examining consumer-brand relationships on social media platforms", Marketing Intelligence \& Planning, Vol. 36 No. 1, pp. 63-78.

Jaiswal, A.K., Niraj, R., Park, C.H. and Agarwal, M.K. (2018), “The effect of relationship and transactional characteristics on customer retention in emerging online markets", Journal of Business Research, Vol. 92, pp.25-35.

Jensen, J. M., and Wagner, C. (2018), “A cross-national comparison of Millennial consumers' initial trust towards an e-travel website", Marketing Intelligence \& Planning. https://doi.org/10.1108/MIP-12-2017-0327. 
Jin, S. V., Muqaddam, A., and Ryu, E. (2019). "Instafamous and social media influencer marketing”. Marketing Intelligence and Planning. https://doi.org/10.1108/MIP-092018-0375

Karjaluoto, H., Mustonen, N., and Ulkuniemi, P. (2015). "The role of digital channels in industrial marketing communications". Journal of Business and Industrial Marketing, Vol. 30 No. 6, pp. 703-710.

Katona, Z., Zubcsek, P.P. and Sarvary, M. (2011), "Network effects and personal influences: The diffusion of an online social network", Journal of marketing research, Vol. 48 No. 3, pp. 425-443.

Kelman, H. (1958), “Compliance, identification, and internalization: three processes of attitude change", Journal of Conflict Resolution, Vol. 2, No. 1, pp. 51-60

Kozinets, R.V. (2002), “The field behind the screen: Using netnography for marketing research in online communities", Journal of marketing research, Vol. 39 No. 1, pp. 61-72.

Kulviwat, S., Bruner II, G.C. and Al-Shuridah, O. (2009), "The role of social influence on adoption of high-tech innovations: The moderating effect of public/private consumption”, Journal of Business Research, Vol. 62, No. 7, pp. 706-712.

Kumar, V. (2018). “Transformative marketing: The next 20 years”, Journal of Marketing, Vol. 82 (July 2018), 1-12.

Kumar, V., Choi, J. B., and Greene, M. (2017). "Synergistic effects of social media and traditional marketing on brand sales: capturing the time-varying effects". Journal of the Academy of Marketing Science, 45(2), 268-288.

Lemon, K. N., and Verhoef, P. C. (2016). “Understanding customer experience throughout the customer journey". Journal of marketing, 80(6), 69-96. 
Lim, H. and Kumar, A. (2017), "Variations in consumers' use of brand online social networking: A uses and gratifications approach”, Journal of Retailing and Consumer Services. https://doi.org/10.1016/j.jretconser.2017.10.015.

Ludwig, S., Ruyter, K. d., Friedman, M., Brüggen, E. C., Wetzels, M. and Pfann, G. (2013), "More than words: The influence of affective content and linguistic style matches in online reviews on conversion rates", Journal of Marketing, Vol. 77, No. 1, pp. 87103.

Lusch, R. F., and Vargo, S. L. (2011). “Service-dominant logic: a necessary step”. European Journal of Marketing, 45(7/8), 1298-1309.

M. Smith, A. (2013). "The value co-destruction process: a customer resource perspective". European Journal of Marketing, 47(11/12), 1889-1909.

Markin, R.J. (1979), “The role of rationalization in consumer decision processes: A revisionist approach to consumer behaviour", Journal of the Academy of Marketing Science, Vol. 7, No 3, pp. 316-334.

Martin, F., and Hutchinson, J. (2018). "Deep Data: Analyzing Power and Influence in Social Media Networks". Second International Handbook of Internet Research, 1-21.

Mathwick, C., Wiertz, C. and De Ruyter, K. (2007), "Social capital production in a virtual P3 community", Journal of consumer research, Vol. 34, No. 6, pp. 832-849.

McColl-Kennedy, J.R., Zaki, M., Lemon, K.N., Urmetzer, F. and Neely, A. (2019), “Gaining customer experience insights that matter", Journal of Service Research, Vol. 22, No. 1, pp. 8-26.

Mitra, D. and Fay, S. (2010), "Managing service expectations in online markets: A signaling theory of e-tailer pricing and empirical tests", Journal of Retailing, Vol. 86, No. 2, pp. 184-199. 
Moorman, C., Deshpande, R., and Zaltman, G. (1993). "Factors affecting trust in market research relationships". Journal of marketing, 57(1), 81-101.

Moran, W.T. (1963), "Practical media decisions and the computer", Journal of Marketing, Vol. 27, No. 3, pp. 26-30.

O' Donohoe, S. (1994), “Advertising uses and gratifications”, European Journal of Marketing, Vol. 28, No. 8/9, pp. 52-75.

Ordenes, F. V., Theodoulidis, B., Burton, J., Gruber, T., and Zaki, M. (2014). “Analyzing customer experience feedback using text mining: A linguistics-based approach”. Journal of Service Research, 17(3), 278-295.

Palmatier, R. W., Dant, R. P., Grewal, D. and Evans, K. R. (2006), "Factors influencing the effectiveness of relationship marketing: A meta-analysis", Journal of Marketing, Vol. 70, No. 4, pp. 136-153.

Pansari, A., and Kumar, V. (2017). "Customer engagement: the construct, antecedents, and consequences". Journal of the Academy of Marketing Science, 45(3), 294-311.

Parasuraman, A. and Grewal, D. (2000), "The impact of technology on the quality-valueloyalty chain: a research agenda", Journal of the Academy of Marketing Science, Vol. 28, No. 1, pp. 168-174.

Payne, A.F., Storbacka, K. and Frow, P. (2008), "Managing the co-creation of value”, Journal of the academy of marketing science, Vol. 36, No. 1, pp. 83-96.

Punyatoya, P. (2019), "Effects of cognitive and affective trust on online customer behaviour", Marketing Intelligence and Planning, Vol. 37, No. 1, pp. 80-96.

Qu, Z., Wang, Y., Wang, S. and Zhang, Y. (2013), “Implications of online social activities for e-tailers' business performance. European Journal of Marketing”, Vol. 47, No. 8, pp. $1190-1212$. 
Quach, S. and Thaichon, P. (2017), "From connoisseur luxury to mass luxury: Value cocreation and co-destruction in the online environment", Journal of Business Research, Vol. 81, pp. 163-172.

Rayna, T. and Striukova, L. 2016, “ $360^{\circ}$ Business Model Innovation: Toward an Integrated View of Business Model Innovation: An integrated, value-based view of a business model can provide insight into potential areas for business model innovation”, Research-Technology Management, Vol. 59, No. 3, pp. 21-28.

Rehnen, L., Bartsch, S., Kull, M. and Meyer, A. (2017), "Exploring the impact of rewarded social media engagement in loyalty programs”, Journal of Service Management, Vol. 28, No. 2, pp. 305-328.

Roshwalb, I. (1956) "Personal Influence: The part played by people in the flow of mass communications" Journal of Marketing, Vol. 21, No. 1, pp. 129-130.

Rust, R.T., Lemon, K.N. and Zeithaml, V.A. (2004), "Return on marketing: Using customer equity to focus marketing strategy", Journal of marketing, Vol. 68, No 1, pp. 109-127. Sánchez-Casado, N., Confente, I., Tomaseti-Solano, E., and Brunetti, F. (2018). "The role of online brand communities on building brand equity and loyalty through relational benefits". Journal of Marketing Theory and Practice, Vol. 26, No. 3, pp. 289-308.

Shaltoni, A.M. (2017), "From websites to social media: exploring the adoption of internet marketing in emerging industrial markets", Journal of Business \& Industrial Marketing, Vol. 32, No. 7, pp. 1009-1019.

Simon, F. (2017), "Relationship norms and media gratification in relational brand communication", Journal of Business Research, Vol. 79, pp. 12-22.

Singer, N, 2018, ‘Weaponized Ad Technology': Facebook’s Moneymaker Gets a Critical Eye, New York Times, https://www.nytimes.com/2018/08/16/technology/facebookmicrotargeting-advertising.html 
Sridhar, S. and Srinivasan, R. (2012), "Social influence effects in online product ratings", Journal of Marketing, Vol. 76, No. 5, pp. 70-88.

Statista (2018), "Global digital population as of July 2018”, Statista, accessed 12 September 2018, from https:/www.statista.com/statistics/617136/digital-population-worldwide/

Steinberg, M. and Plank, R.E. (1987), "Expert systems: the integrative sales management tool of the future", Journal of the Academy of Marketing Science, Vol.15, No. 2, pp. 55-62.

Stephen, A.T. and Toubia, O. (2010), "Deriving value from social commerce networks", Journal of marketing research, Vol. 47, No. 2, pp. 215-228.

Thaichon, P. (2017), “Consumer socialization process: The role of age in children's online shopping behaviour", Journal of Retailing and Consumer Services, Vol. 34, No. 1, pp. $38-47$.

Thaichon, P., Surachartkumtonkun, J., Quach, S., Weaven, S. and Palmatier, R.W. (2018), "Hybrid sales structures in the age of e-commerce", Journal of Personal Selling \& Sales Management, Vol. 38, No.3, pp. 277-302.

Thompson, C. J. and Arsel, Z. (2004), "The Starbucks brandscape and consumers' (anticorporate) experiences of glocalization”, Journal of consumer research, Vol. 31, No. 3, pp. 631-642.

Tiwana, A.B. (1998), "Interdependency factors influencing the World Wide Web as a channel of interactive marketing”, Journal of Retailing and Consumer Services, Vol. 5, No. 4, pp. 245-253.

Trainor, K. J., Andzulis, J. M., Rapp, A., and Agnihotri, R. (2014). "Social media technology usage and customer relationship performance: A capabilities-based examination of social CRM". Journal of Business Research, 67(6), 1201-1208. 
van Dieijen, M., Borah, A., Tellis, G. J., and Franses, P. H. (2019). "Big Data Analysis of Volatility Spillovers of Brands across Social Media and Stock Markets”. Industrial Marketing Management.

Vargo, S.L. and Lusch, R.F. (2004), "Evolving to a new dominant logic for marketing", Journal of Marketing, Vol. 68, No. 1, pp. 1-17.

Walsh, G., Hennig-Thurau, T., Sassenberg, K., and Bornemann, D. (2010). “Does relationship quality matter in e-services? A comparison of online and offline retailing”. Journal of Retailing and Consumer Services, 17(2), 130-142.

Wang, Y., and Li, D. (2013). "Testing the moderating effects of toolkits and user communities in personalization: The case of social networking service". Decision Support Systems, Vol. 55, No.1, pp. 31-42.

Wang, Y., Hsiao, S.H., Yang, Z. and Hajli, N. (2016), “The impact of sellers' social influence on the co-creation of innovation with customers and brand awareness in online communities", Industrial Marketing Management, Vol. 54, No. 1, pp. 56-70.

Wang, Z., and Kim, H. G. (2017). "Can social media marketing improve customer relationship capabilities and firm performance? dynamic capability perspective". Journal of Interactive Marketing, Vol. 39, pp. 15-26.

Weiber, R. and Kollmann, T. (1998), "Competitive advantages in virtual marketsperspectivesof 'information-based marketing' in cyberspace”, European Journal of Marketing, Vol. 32, No. 7/8, pp. 603-615.

Yuan, Y., Caulkins, J.P. and Roehrig, S. (1998), "The relationship between advertising and content provision on the Internet", European Journal of Marketing, Vol. 32, No. 7/8, pp. 677-687. 
Yuan, Y., Caulkins, J.P. and Roehrig, S. (1998), “The relationship between advertising and content provision on the Internet", European Journal of Marketing, Vol. 32, No. 7/8, pp. 677-87.

Zhang, B. and Sundar, S.S. 2019, "Proactive vs. reactive personalization: Can customization of privacy enhance user experience?", International Journal of Human - Computer Studies, Vol. 128, pp. 86-99.

Zhang, R., Li, G., Wang, Z. and Wang, H. (2016), "Relationship value based on customer equity influences on online group-buying customer loyalty", Journal of Business Research, Vol. 69, No. 9, pp. 3820-3826.

Zhang, T., Lu, C., Torres, E. and Chen, P.J. (2018), "Engaging customers in value co-creation or co-destruction online”, Journal of Services Marketing, Vol. 32, No. 1, pp. 57-69. 